\title{
The Anti-Proliferative and Pro-Apoptotic Properties of Ethanol Plectranthus amboinicus (Lour.) Spreng. Leaves Ethanolic Extract Nanoparticles on T47D Cell Lines
}

\author{
Poppy Anjelisa Zaitun Hasibuan ${ }^{1,2 *}$, Sumaiyah Sumaiyah ${ }^{3}$
}

\begin{abstract}
Objectives: Plectranthus amboinicus (Lour.) Spreng. is a plant which has the potential as an anti-cancer agent. To enhance the bioavailability of an extract, it is necessary to transform the extract into nanoparticles. This research aimed to create nanoparticles of the extract and investigate the anti-proliferative and pro-apoptosis effects on T47D breast cancer cell lines. Materials and Methods: The extraction with ethanol was performed using maceration method. The nanoparticles were prepared by using the ionic gelation method. Cytotoxic assay method evaluation of the proliferation of T47D cell line (using doubling time) was carried out using the MTT assay. Apoptosis was observed using the flow cytometry assay. Results: Treatment with Plectranthus amboinicus (Lour.) Spreng. ethanolic extract nanoparticles (PAEEN) inhibited the proliferation of T47D cell lines after 48 hours and 72 hours of incubation at concentrations of $22.3 \mu \mathrm{g} / \mathrm{mL}, 44.6 \mu \mathrm{g} / \mathrm{mL}$, and $89.2 \mu \mathrm{g} / \mathrm{mL}$. The viable cells were $93 \%, 86 \%, 54 \%$ (48 hours), and $98 \%, 71 \%, 57 \%$ (72 hours), respectively. The nanoparticles of extract also induced apoptosis at concentrations of $1 / 4 \mathrm{IC}_{50}(2.16 \%), 1 / 2$ $\mathrm{IC}_{50}(1.57 \%)$, and $\mathrm{IC}_{50}(2.43 \%)$. Conclusion: PAEEN exhibits the anti-proliferative effect on T47D breast cancer cells via apoptosis. Further study is required to confirm the mechanism of PAEEN in the cell cycle arrest and apoptosis induction on T47D cells.
\end{abstract}

Keywords: Plectranthus amboinicus- (Lour.) Spreng., antiproliferative- apoptosis- nanoparticles

Asian Pac J Cancer Prev, 20 (3), 897-901

\section{Introduction}

Cancer is the second leading cause of death in many countries. Unfortunately, the current classical treatments are impeded by a multitude of side effects, such as the development of tumor resistance, loss of appetite, nausea, vomiting, hair loss, lowered resistant to infections, hemorrhage, and diarrhea (Lifiani et al., 2018). Therefore, finding a novel and effective therapeutic compound, enhancing its bioavailability against cancer, and at the same time being able to reduce the dosage of the medicine becomes the current scientific challenges.

The in vitro cytotoxic property of Plectranthus amboinicus (Lour.) Spreng. leaves' crude extract was tested against HeLa, MCF7, and T47D cell lines. Previous studies have shown that the n-hexane, ethyl acetate, and ethanol extracts had cytotoxic effects on HeLa cells at an inhibitory concentration of $50 \%\left(\mathrm{IC}_{50}\right)$ with values of $76.322 \mu \mathrm{g} / \mathrm{mL}, 143.291 \mu \mathrm{g} / \mathrm{mL}$, and $88.997 \mu \mathrm{g} / \mathrm{mL}$, respectively (Bharti, et al., 2015). Furthermore, it also exhibited strong cytotoxic effects on MCF7 cell lines (Bruzea et al., 2007).

$\mathrm{N}$-hexane and ethyl acetate extracts showed strong cytotoxic effects on T47D breast cancer cells with $\mathrm{IC}_{50}$ values of $44.716 \mu \mathrm{g} / \mathrm{mL}$ and $37.61 \mu \mathrm{g} / \mathrm{mL}$, respectively. The combination of Plectranthus amboinicus (Lour.) Spreng. and doxorubicin which inhibited the HeLa cell lines in $1 / 4,3 /(8)$, and $1 / 2 \mathrm{IC}_{50}$ values and $1 / 2 \mathrm{IC}_{50}$ value of doxorubicin $(0.6 \mu \mathrm{g} / \mathrm{mL})$ resulted in a strong synergistic effect with Combination Index value below 0.1 $(\mathrm{CI}<0.1)$. It showed the same effect with the combination of doxorubicin which inhibited T47D cell line (Hameed et al., 2016).

Targeting a drug to its specific cells is a significant challenge in designing a drug delivery system for cancer treatment. Nanoparticles form an ideal solution for anti-cancer drugs with improved selectivity and reduced side-effects toward tumor cells. Drug-loaded nanoparticles can be created to perform more complex and cooperative targeting functions (Hasibuan et al., 2015; Hasibuan et al., 2013).

\section{Materials and Methods}

Plant Material

Plectranthus amboinicus (Lour.) Spreng. leaves

${ }^{1}$ Nanomedicine Center of Innovation, ${ }^{2}$ Department of Pharmacology Pharmacy, ${ }^{3}$ Department of Pharmaceutical Technology, Faculty of Pharmacy, University Sumatera Utara, Indonesia.*For Correspondence: poppyanjelisa@usu.ac.id 
were obtained from Pematang Siantar, North Sumatera, Indonesia. The leaves were identified in the Research Centre for Biology, Indonesian Institute of Science, Bogor while the voucher specimen was deposited in an herbarium. The leaves of Plectranthus amboinicus (Lour.) Spreng. were dried at $45^{\circ} \mathrm{C}$ and mashed into powder.

\section{Chemicals and reagents}

Ethanol purchased from Merck (Darmstadt, Germany), dimethyl sulfoxide (Sigma-Aldrich, Germany), [3-(4,5-dimethylthiazol-2-yl)-2,5-diphenyl tetrazolium bromide] (MTT) (Sigma Chemical, St. Louis, MO), RPMI media and phosphate buffer saline, foetal bovine serum (FBS) 10\% v/v (Gibco, Grand Island, NY, USA), sodium tripolyphosphate (Sigma), and glacial acetic acid (Merck). The water used in this research was deionized water.

The preparation of Plectranthus amboinicus (Lour.) Spreng. leaves ethanolic extract nanoparticles (PAEEN)

Ionic gelation method was performed for the preparation of Plectranthus amboinicus leaves ethanolic extract nanoparticles. $0.3 \%$ PAEEN was prepared in $1.5 \%$ acetic acid. The Plectranthus amboinicus (Lour.) Spreng. leaves ethanolic extract nanoparticles were prepared by adding sodium tripolyphosphate $(1 \mathrm{mg} / \mathrm{ml})$ dropwise under magnetic stirring at room temperature for an hour. The mixture result was separated by centrifugation at the speed of 15,000 rpm for 20 minutes. The pellet was collected and used for characterization (llian et al., 2018).

1 gram of Plectranthus amboinicus leaves ethanolic extract was diluted into $35 \mathrm{~mL}$ of ethanol p.a, added with $15 \mathrm{~mL}$ of distilled water, chitosan in $100 \mathrm{~mL}$ of glacial acetic acid $1 \%$, and $350 \mathrm{~mL}$ of NaTPP solution. The mixture was stirred by using magnetic stirrer for \pm 2 hours. After that, the colloid of nanoparticle chitosan-NaTPP of Plectranthus amboinicus leaves ethanolic extract was separated by centrifugation. The result was put into a freezer $\left( \pm-4^{\circ} \mathrm{C}\right)$ for \pm 2 days. It was then moved into a refrigerator $\left( \pm 3^{\circ} \mathrm{C}\right)$ to make it dried. The resulting nanoparticles were characterized using PSA (Particle Size Analyzer) whereas the formed solids were characterized using TEM (Transmission Electron Microscope) to determine the morphological form of its solid form (Ozcelik et al., 2004).

\section{Cytotoxicity and anti-proliferative activity assay}

The cells were treated with PAEEN. In this test, T47D cell lines were grown in RPMI 1640 medium containing 10\% Fetal Bovine Serum (Gibco), 1\% penicillin-streptomycin (Gibco), and fungizone $0.5 \%$ (Gibco) in a humid atmosphere $\left(5 \% \mathrm{CO}_{2}\right)$ at a temperature of $37^{\circ} \mathrm{C}$. The inoculums were seeded at $1 \times 10^{4}$ cells $/ \mathrm{mL}$ with an optimal volume of $0.1 \mathrm{~mL}$ per well. After 24 hours of incubation, the medium was discharged and treated with PAEEN. After 24 hours of incubation, the cells were incubated again with $0.5 \mathrm{mg} / \mathrm{mL}$ of MTT for 4 hours at $37^{\circ} \mathrm{C}$. Viable cells reacted with MTT and produced purple formazan crystals. After 4 hours, $10 \% \mathrm{SDS}$ as the stopper (Sigma) was added in $0.01 \mathrm{~N}$ of $\mathrm{HCl}$ (Merck) to dissolve the formazan crystals. The cells were then incubated for 24 hours at room temperature and were kept away from light. After the incubation, the cells were shaken, and absorbance was measured using ELISA reader at $\lambda 595$ $\mathrm{nm}$. The measured data from each well were converted to the percentage of viable cells (Hameed et al., 2016). The cell growth inhibition was calculated using the formula Rosidah et al., 2014; Rusdi et al., 2018; Sumaiyah et al., 2014).

Percentage of viable cell $=($ Absample-Abmedium $) /$ (Abcontrol-Abmedium) x 100\%

The anti-proliferative activity was also determined using the MTT assay with the same procedure. Cells were cultured in RPMI and exposed to various concentrations of PAEEN for 4 days. The absorbance of the MTT incubated cells were measured with ELISA reader at 0, 24, 48, and 72 hours.

\section{Detection of Apoptosis (Flow cytometry assay)}

T47D cells were seeded into 6-well plates and incubated for 24 hours. After treated with PAEEN and incubated for 24 hours, the floating and adherent cells were collected in a conical tube using $0.025 \%$ trypsin. The cells were cleaned thrice with cold PBS and separated by centrifugation with the speed of 2,500 rpm for 5 minutes. The supernatant was separated while the sediment was collected and fixed in cold $70 \%$ ethanol in PBS at $-20^{\circ} \mathrm{C}$ for 2 hours. The cells were cleaned thrice with cold PBS, suspended, and separated by centrifugation with the speed of 3,000 rpm for 3 minutes. Annexin V kit was added to the sediment, suspended, and incubated at $37^{\circ} \mathrm{C}$ for 30 min. The samples were analyzed using FAC Scan flow cytometer (Kadian et al., 2018).

\section{Statistical Analysis}

The results were expressed as mean \pm SEM. The mean difference of the cell viability assays between experimental groups was determined using one-way ANOVA, followed by the Tukey test. All experiments were carried out in triplicate.

\section{Results}

The Plectranthus amboinicus (Lour.) Spreng. leaves ethanol extract nanoparticles (PAEEN)

The study aimed to evaluate the anti-proliferative and induce apoptosis of PAEEN on T47D breast cancer cells. The preparation of Plectranthus amboinicus (Lour.) Spreng. leaves ethanol extract was performed using the maceration method with $96 \%$ ethanol followed by evaporation to form viscous extracts. Colloidal nanoparticles were made by mixing the viscous extracts of Plectranthus amboinicus (Lour.) Spreng. leaves with ethanol, distilled water, chitosan solution in glacial acetic acid, and STPP. There were nine variations of chitosan and STPP composition ratio. Colloidal nanoparticles were separated by centrifugation aimed to separate the precipitation of fingerroot nanoparticles. After that, Plectranthus amboinicus (Lour.) Spreng. leaves extract sediment was kept in a freezer. The characterization of Plectranthus amboinicus (Lour.) Spreng. leaves extract 
Table 1. The Percentage of Viable Cell, Early Apoptotic and Necrotic Cell

\begin{tabular}{lcccc}
\hline Condition of cells & \multicolumn{4}{c}{ Percentage of cells (\%) } \\
& $1 / 4 \mathrm{IC}_{50}$ & $1 / 2 \mathrm{IC}_{50}$ & $\mathrm{IC}_{50}$ & Control \\
& & & & cell \\
\hline Viable cell (LL) & 41.46 & 4.33 & 0.77 & 92.38 \\
Apoptotic cell (LR) & 2.33 & 1.4 & 0.21 & 1.19 \\
Late apoptotic cell (UR) & 4.57 & 4.07 & 2.43 & 1.46 \\
Necrotic cell (UL) & 52.84 & 90.22 & 96.62 & 5.03 \\
\hline
\end{tabular}

LL, lower left; LR, lower right; UR, upper right; UL, upper left
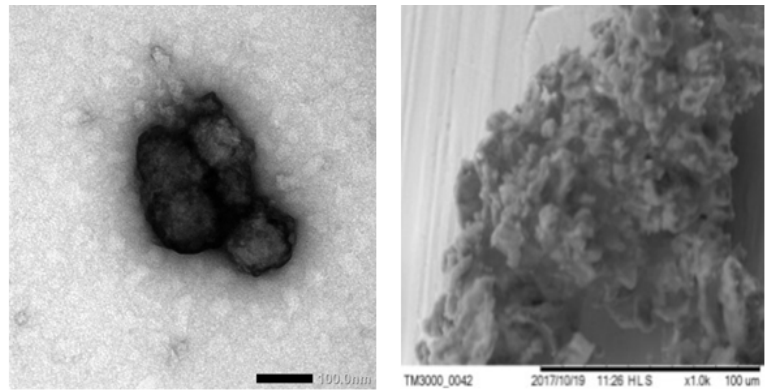

Figure 1. The Morphology of PAEEN by TEM Analysis

in nanoparticle size was performed using Particle Size Analyzer (PSA). The results of PAEEN in the nanoparticle size using PSA (Particle Size Analyzer) can be seen in Table 1. The formula using the concentration ratio of chitosan and STPP $(8: 1)$ or $0.08 \%$ chitosan and $0.01 \%$ STPP produced the smallest size of PAEEN which was $585.09 \mathrm{~nm}$.

The morphology of precipitated nanoparticles was characterized using Transmission Electron Microscopy (TEM) (Martien et al., 2012). Characterization using PSA showed the nanoparticle size of $389-877 \mathrm{~nm} 98.1 \%$ with the concentration ratio of chitosan and STPP $=8: 1$. The average of zeta potential value was $41.87 \mathrm{mV}$. The outcome from TEM exhibits the morphology of the precipitated particle. The morphology of PAEEN can be seen in Figure 1.

The morphology of PAEEN was analyzed by using TEM. It displayed that the particles aggregated between one another. The TEM image showed that the particle size of PAEEN was in the range of 80-120 nm. The nanoparticles of Plectranthus amboinicus (Lour.) Spreng. leaves extract were successfully made because the size was in the range of $1-1,000 \mathrm{~nm}$ (Martien et al., 2012).

\section{Effect of PAEEN on T47D proliferation}

In the present study, the effect of PAEEN on T47D cell lines was examined. Cytotoxic assay of PAEEN on T47D cells was exposed to various concentrations of PAEEN $(15.625,31.25,62.50,125,250$, and $500 \mu \mathrm{g} / \mathrm{mL})$. Cells treated with $0.1 \%$ DMSO were used as the control. The cytotoxic assay gave reproducible dose-response curves over a concentration range (Saleem et al., 2002). The cell viability decreased with the increasing concentrations of PAEEN, and the $\mathrm{IC}_{50}$ value of PAEEN was $89.166 \mu \mathrm{g} / \mathrm{mL}$.

The anti-proliferative activity of PAEEN against T47D cells at $1 / 4 \mathrm{IC}_{50}(22.3 \mu \mathrm{g} / \mathrm{mL}), 1 / 2 \mathrm{IC}_{50}(44.6 \mu \mathrm{g} / \mathrm{mL})$ and $\mathrm{IC}_{50}(89.166 \mu \mathrm{g} / \mathrm{mL})$ through incubation for 24,48 , and 72 hours. The selection of $1 / 4$ and $1 / 2$ concentration was done so that only a few cells die at the observation time to obtain the proliferation kinetics data of T47D cells after the administration of PAEEN. Interestingly, the viability of the cells increased at 24 hours, and PAEEN suppressed the number of T47D cells. As shown in Figure 2, PAEEN inhibited the proliferation of T47D after 48 hours. The nanoparticles of the extract exhibited the most effective impact in decreasing the number of T47D cells at $\mathrm{IC}_{50}$ concentration $(89.2 \mu \mathrm{g} / \mathrm{mL})$.

\section{Effect of PAEEN on the apoptosis of T47D breast cancer} cells

In order to determine whether the anti-proliferative effect of PAEEN was due to apoptosis, T47D cells were treated with PAEEN for 24 hours. The study aimed to evaluate apoptosis induced with the flow cytometry

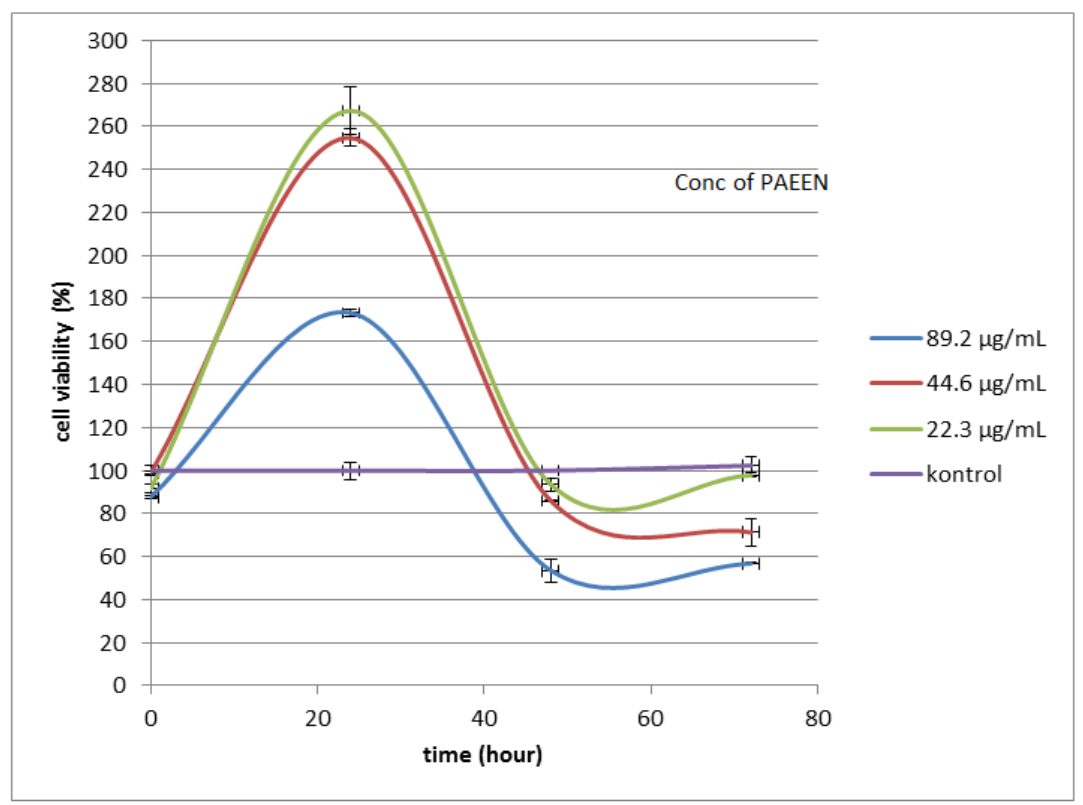

Figure 2. Effect of Different Doses of PAEEN on the Viability of T47D Cells. Data are expressed as mean \pm SEM. $n=$ 3 wells for each group. 


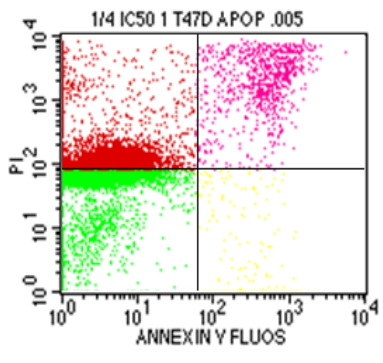

(a) PAEEN $1 / 4 \mathrm{IC}_{50}$

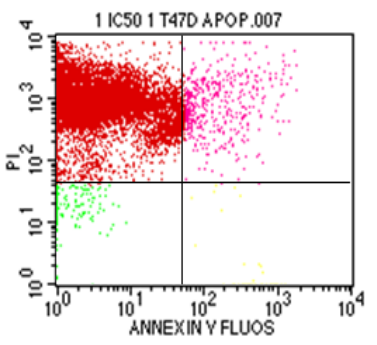

(c) PAEEN IC 50

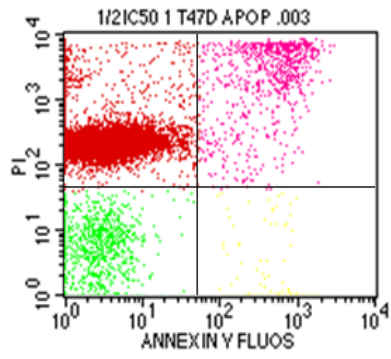

(b) PAEEN $1 / 2 \mathrm{IC}_{50}$

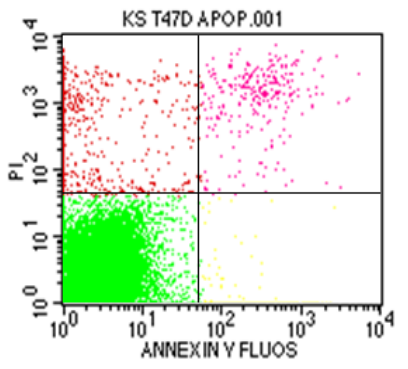

(d) Control cell T47D

Figure 3. Apoptotic Analysis of T47D Treated with PAEEN for 24 hours and Stained Using Annexin-V. (a) PAEEN 1/4 IC50 (22.3 $\mu \mathrm{g} / \mathrm{mL})$; (b) PAEEN $1 / 2$ IC50 (44.6 $\mu \mathrm{g} / \mathrm{mL})$; (c) PAEEN IC50 (89.2 $\mu \mathrm{g} / \mathrm{mL})$; and (d) control cells

assay and Annexin-V. The apoptosis on T47D cells had a higher percentage than the control cells which means that the concentration of PAEEN with $1 / 4 \mathrm{IC}_{50}, 1 / 2 \mathrm{IC}_{50}$, and $\mathrm{IC}_{50}$ could trigger the cell apoptosis. As shown in Figure 3 , the cells in the lower right and upper right quadrants represent early apoptotic and late apoptotic or necrotic cells, respectively. The viable and late necrotic cells were represented in the lower left and upper left quadrants, respectively.

Based on the flow cytometry assay above, the percentage of viable, early apoptotic, and necrotic cells can be seen in Table 1.

PAEEN induced the early apoptosis and late apoptosis in cells with a higher percentage than the T47D control cell lines. The $1 / 4 \mathrm{IC}_{50}$ PAEEN gave the highest percentage of apoptosis condition compared to the other two concentrations of PAEEN.

\section{Discussion}

Nanoparticles form is an ideal solution for the anti-cancer drugs with improved selectivity and reduced side-effects toward the tumor cells. Drug-loaded nanoparticles can be developed to perform more complex, cooperative targeting functions (Hasibuan et al., 2016; Raj et al., 2015).

Plectranthus amboinicus (Lour.) Spreng. leaves extract have attracted considerable interest as alternative cancer remedies because of low toxicity and the ability to affect cells with different mechanisms, such as by preventing initiation and promotion of carcinogenesis or apoptosis induction. Cytotoxic tests on n-hexane, ethyl acetate, and ethanol extract of Plectranthus amboinicus (Lour.) Spreng. have been done in our previous study. The results showed that $n$-hexane and ethyl acetate extract had strong cytotoxic effects on MFC7 cells with $\mathrm{IC}_{50}$ values of $63.64 \mu \mathrm{g} / \mathrm{mL}$ and $7.65 \mu \mathrm{g} / \mathrm{mL}$, respectively. In contrast, the ethanol extract had an $\mathrm{IC}_{50}$ value of $1,382.8 \mu \mathrm{g} / \mathrm{mL}$ which means that it had no cytotoxic effect (Bruzea et al., 2007). The multilevel extraction process resulted in secondary metabolites contained in Plectranthus amboinicus (Lour.) Spreng. leaves to be extracted in n-hexane and ethyl acetate solvents, and only a little was found in ethanol extract. This is likely to be the cause that ethanol extract has no effect. In the present study, we extracted Plectranthus amboinicus (Lour.) Spreng. leaves directly with ethanol solvent and made the extract into a nanoparticle size, and $\mathrm{IC}_{50}$ value obtained was $89.166 \mu \mathrm{g} / \mathrm{mL}$. The extract has the potential to be developed as an anti-cancer drug if it has an $\mathrm{IC}_{50}$ value below $100 \mu \mathrm{g} / \mathrm{mL}$ (Kamuhabwa et al., 2000). Anti-proliferation of PAEEN may be achieved through inhibition of pro-oxidant agents, such as reactive oxygen species (ROS). They initiate tumor promotion and acts as the main catalyst for progression and promotion of tumor to the initiation stage (Kwon et al., 2006). Apoptosis, which is a major way to program the death of a cell, plays an important role in the regulation of tissue development and homeostasis in eukaryotes. Homeostatic between cell death and cell proliferation is required to maintain a normal state11. PAEEN may induce apoptosis through p53, down-regulation of Bcl-2, and up-regulation of Bax. The possible mechanism in which $\mathrm{p} 53$ regulates apoptosis involves the activation of mitochondria-regulated death pathway by elevating gene expression of pro-apoptosis in the Bcl-2 family and suppressing the expression of anti-apoptosis genes (Lotha et al., 2018).

The ability of PAEEN in triggering apoptosis might be due to its smaller size, given the greater surface area and distinct physical and chemical properties. Nanoparticle properties can occur in all biological systems, organs, or tissues (Hasibuan et al., 2013). Hence, nanoparticles 
can interfere with overexpressed proteins proliferation which causes death in targeted cells. Nanoparticles also show the capacity to overcome multidrug resistance in chemotherapy (Kamuhabwa et al., 2000; Martien et al., 2013). Figure 2 shows that the cell viability was quite high at the 24th hour while the apoptosis test using the flow cytometry method shows that the number of cells experiencing death for both necrosis and apoptosis after 24 hours of incubation appeared quite high (Table 1). Although it was a contradictory phenomenon, it can be explained based on the administration time of the extract to the cells. In the anti-proliferation test, PAEEN was given after the cells were incubated for 24 hours which allowed the cells to proliferate from 0 to 24 hours. In contrast, in the apoptosis test, PAEEN was administered 24 hours before the second incubation, and the observation was performed on the following day. Thus, there had been a decrease in the viability of T47D cells which were likely to have experienced apoptosis and necrosis.

In conclusion, PAEEN could inhibit proliferation and trigger apoptosis of T47D cell lines. PAEEN exhibited anti-proliferative effects on T47D breast cancer cells via apoptosis.

\section{Conflicts of interest}

The authors declare that there are no conflicts of interest.

There is no requirement for ethical approval.

\section{Acknowledgements}

We express our gratitude to the University of Sumatera Utara, Indonesia through "Hibah Talenta" Research Grant 2018 no.233/UN5.2.3.1/PPM/KP-TALENTA USU/2018 for the financial support in this study.

\section{References}

Alshatwi AA, Hasan TN, Shafi G, et al (2012). Validation of the antiproliferative effects of organic extracts from the green husk of Juglans regia L. on PC-3 human prostate cancer cells by assessment of apoptosis-related genes. J Evid Based Complementary Altern Med, 2012, 103026.

Bharti V, Gupta UD, Das SN (2015). Commiphora mukul extract and guggulsterone exhibit antitumour activity trough inhibition of Cyclin D1, BFK and induction of apoptosis in oral cancer cells. Asian J pharm Clin Res, 8, 291-5.

Bruzea C, Pacheco I, Robbie K (2007). Nanomaterials and nanoparticles: Source and toxicity. J Bioint, 2, 17-71

Hameed H, Aydin S, Basaran AA, et al (2016). Assessment of cytotoxic properties of sinapic acid in vitro. Turk $J$ Pharm Sci, 13, 225-32

Hasibuan PAZ, Chrestella J, Satria D (2015). Combination effect of ethylacetate extracts of Plectranthus amboinicus (Lour.) Spreng. with doxorubicin againts T47D breast cancer. Int $J$ Pharmacy Pharm Sci, 7, 156-9.

HAsibuan PAZ, Ilyas S, Nasution MP (2013). Antioxidant activity of n-hexane, etylacetate and ethanolic extract of plectranthus amboinicus (Lour.) Spreng by DPPH and caroten - linoleic acid methods. Int $J$ Pharmacy Teach Pract, 4, 755-8.

Illian DN, Basyuni M, Wati R, et al (2018). Polyisoprenoid from Avicennia marina and Avicennia lanata inhibit WiDr cells proliferation. Pharmacog Mag, 14, 513.

Kadian R (2018). Nanoparticles: a promising drug delivery approach. Asian J Pharm Clin Res, 11, 30-5

Kamuhabwa A, Nshimo C, Witte P (2000). Cytotoxicity of some medicinal plant extracts used in Tanzanian traditional medicine. J Ethnopharmacol, 70, 143-7.

Kwon HJ, Hong YK, Kim KH, et al (2006). Methanolic extract of Pterocarpus santalinus induces apoptosis in HeLa cells. J ethnopharm, 105, 229-34

Lifiani R, Harahap U, Hasibuan PAZ, et al (2018). Anticancer effect of african leaves (Vernonia amygdalina del,) to T47D cell resistant. Asian J Pharm Clin Res, 11, 1-7

Lotha R, Sivasubramanian A (2018). Flavonoids nutraceuticals in prevention and treatment of cancer: a review. Asian $J$ Ppharm Clin Res, 11, 42-7

Martien R, Adhyatmika A, Irianto ID, et al (2012). Perkembangan teknologi nanopartikel sebagai sistem penghaantaran obat. Maj Farmaset, 8, 133-44

Ozcelik B, Karaoglu T, Abbasoglu U (2004). Evaluation of cytotoxicity of some agents as a screening test in antitumoral activity using vero, HeLa, and Hep-2 cell cultures. Turk $J$ Pharm Sci, 1, 153-63

Raj LFAA, Jonisha R, Revathi B, et al (2015). Preparation and characterization of BSA and chitosan nanoparticles for sustainable delivery system for quercetin. $J$ Appl Pharm Sci, 1, 153-63.

Rosidah, Hasibuan PAZ (2014). Cytotoxic effect of n-hexane, ethylacetate and ethanol extracts of Plectranthus amboinicus (Lour) spreng on Hela and vero cell lines. Int J Pharmtech Res, 6, 1806-9.

Rusdi IY, Dalimunthe A (2018). The preparation and characterization of ethanol extract nanoparticle from Raphidophora pinnata (Lf) schott leaves by using arabic gum and dextrin. $J$ Young Pharm, 10.

Saleem A, Husheem M, Harkonen P, et al (2002). Inhibition of cancer cell growth by crude extract and the phenolic of terminalia chebula retz fruit. J Ethnopharm, 81, 327-36.

Sumaiyah, Wirjosentono B, Nasution MP, et al (2014). Preparation and characterization of nanocrystalline cellulose from sugar palm bunch (Arenga pinnata (wurmb)Merr.). Int $J$ Pharmtech Res, 6, 814-20.

Tyaboonchai W (2013). Chitosan nanoparticles: a promising system for drug delivery. Nar Univ J, 11, 51-66.

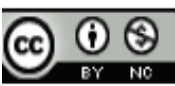

This work is licensed under a Creative Commons AttributionNon Commercial 4.0 International License. 